\title{
Application of Taguchi design in the removal of heavy metals from Simulated metal solutions using groundnut shell and tea bag as a natural absorbent
}

\author{
David Ebuka Arthur ${ }^{1 *}$ and Augustina Aroh Oyibo ${ }^{2}$
}

\begin{abstract}
Background: A series of metal solutions such as chromium sulphate, lead sulphate and nickel sulphate were prepared, and varying concentrations were used to model the optimum conditions that would favour the removal of these metals in polluted situations. Taguchi design was used to set the experiment in motion by using three factors such as $\mathrm{pH}$, concentration and time, although the experiment was done at a fixed temperature of $30^{\circ} \mathrm{C}$ as detailed in the study.

Result: The percentage of heavy metals removal from the solutions at varying conditions was used to model the effectiveness of the adsorbent. All models and their statistical parameters were reported in the study. The model identified as the best was the one involving the removal of chromium concentration using the tea bag adsorbent. The ability of the model to predict other concentrations which were not used in developing the model was high and was reported as pre $R^{2}$ of 0.94 .

Conclusion: The model predicts that the experiment which was conducted at varying $\mathrm{pH}$ values ranging from $1.00-8.00$ can lead to the effective removal of chromium by decreasing the $\mathrm{pH}$ of the system to $\mathrm{pH}$ value $=1$, and increasing the contact time of the adsorbent tea bag residue. The model confirms the transformation of chromium from hexavalent to trivalent at acidic pH which decreases its ionic solubility in an aqueous system leads to its ultimate removal by the adsorbent
\end{abstract}

Keywords: Heavy metals, Adsorbent, Tea bag, Models, Taguchi design

\section{Background}

The knowledge of increasing water pollution suggests a lot of work has been done on water treatment. Removal of heavy metal ions in waste water from chemical industries is of growing concern. In the past, natural waste materials such as groundnut shell were explored for heavy metal removal. Lately, efforts have been made to optimize this material for a higher work efficiency. Natural plant materials such as groundnut shell and used tea bag are waste

\footnotetext{
*Correspondence: davidebukaarthur@gmail.com

${ }^{1}$ Department of Chemistry, Baze University Abuja, Abuja, Nigeria Full list of author information is available at the end of the article
}

materials that when recycled have the potential to source low-cost adsorbent and activated charcoal precursors since they are cheap unused resources and are widely accessible.

The use of economical natural absorbent such as activated charcoal, agricultural produce and waste byproducts for the removal of heavy metals was reported in the past by numerous researchers (Abdel-Shafy and Mansour 2018). Most of these studies recognized the use of natural adsorbent as possible alternative to the standard methods like ion exchange, precipitation and liquid membrane for exclusion of heavy metals ions found in industrial waste water since these techniques 
have some economical constraints (Nguyen and Do 2001).

Groundnut shell primarily consists of carbonaceous fibrous material commonly regarded as waste and can be used for so many application, and normally utilized for its value as a fuel source (Abdel-Shafy et al. 1998). It is also used as an adsorbent to take away of heavy metal present usually in their ionic states. Some of these metals reported in the literature include chromium (III), nickel (Ni), lead (Pb). Groundnut shell is environmentally friendly and trustworthy adsorbent source, which is one of the renewable agricultural waste products (Parker 1999). And also green tea is one of the most popular beverage in the world, and also the agricultural product that is very useful, which is about 3.5 million tones of a green tea was reported to be used per annum in the world (Parasad et al. 2008).

Amarasinghe et al. (2007) used tea bag waste as economical adsorbent for the exclusion of $\mathrm{Pb}$ and $\mathrm{Cu}$ from waste water. The percentage removal of $\mathrm{Cu}$ was $87 \%$, Pb was $90 \%$. Cay et al. (2004) were investigated the exclusion of $\mathrm{Cu}$ (II) and Cd (II) single (non-competitive) and binary (competitive) in aqueous system, the exclusion of $\mathrm{Cu}$ (II) $95 \%$ and Cd (II) $75 \%$. Malkoc et al. (2005) were investigated for the deletion of nickel from waste water by maximum removal of the $\mathrm{Ni}$ was 95\%. Henderson et al. (1997) have investigated the effectiveness of a number of diverse organic waste resources as adsorbent for heavy-metal removal. These includes coconut shell, rice husk and peanut shell, and so confirms the common knowledge that agricultural product are very good adsorbent (Abdel-Shafy 2015; Abdel-Shafy and Mansour 2018).

Taguchi method is a statistical method developed by Taguchi and Konichi (G Taguchi and Konishi 1987). In this paper, the Taguchi design was used in optimizing the adsorption parameters. It is an essential device used in designing this experiment and employed to attain a percentage of heavy metal removed without increasing cost. In recent times, the Taguchi method has been generally engaged in a number of industrial fields and research works (Genichi Taguchi 1995; Genichi Taguchi and Jugulum 2002).

This research aims to analysed some metals which is $\mathrm{Pb}, \mathrm{Cr}$, and $\mathrm{Ni}$ in sample of groundnut shell and tea bag, where research of these type are very rare or yet to be conducted. With these, the problem reported in the previous research will be compared with this present research and to see whether these metals are present in groundnut shell and tea bag.

\section{Methods}

\section{Preparation of adsorbent}

The groundnut shell and tea bag were collected from the samaru market. The groundnut shell was washed with distilled water and dried it in hot oven at $105^{\circ} \mathrm{C}$ for $12 \mathrm{~h}$. After drying, the sample was pulverized and separated into fine particle sizes using a mesh sieving machine. The sample tea bag containing a litre of distilled water was warmed with a hot plate at $85{ }^{\circ} \mathrm{C}$ until the colour removed. After colour removal, the tea bag was dried in the oven at $105^{\circ} \mathrm{C}$ for a period of $12 \mathrm{~h}$. The dried sample was pulverized into powder and stored in sealed polythene bags. The two pulverized samples were directly for the experiment without any physical chemical treatment as an adsorbent.

\section{Preparation of adsorbates}

The chemical used here is of analytical grade, they were purchased from Sigma-Aldrich and their percentage purity is given as Nickel(II) sulphate hexahydrate.

$\mathrm{NiSO}_{4} 6 \mathrm{H}_{2} \mathrm{O}$ (98\%), lead (II) sulphate $\mathrm{PbSO}_{4} 8 \mathrm{H}_{2} \mathrm{O}$ (98\%), while $\mathrm{CrSO}_{4} 7 \mathrm{H}_{2} \mathrm{O}$ (98\%) was obtained from a chemical store in Zaria and used without subjecting to any further purification techniques. $100 \mathrm{~cm}^{3}$ stock solution was prepared for each metal.

1 Nickel solution: $4.467 \mathrm{~g}$ of $\mathrm{NiSO}_{4} 7 \mathrm{H}_{2} \mathrm{O}$ was added in the $100 \mathrm{~cm}^{3}$ of distilled water in $1000 \mathrm{~cm}^{3}$ volumetric flask. It was dissolved by agitation after which the volume was filled to the mark with deionized water.

2 Lead solution: $4.251 \mathrm{~g}$ of $\mathrm{PbSO}_{4} .8 \mathrm{H}_{2} \mathrm{O}$ was added in the $100 \mathrm{~cm}^{3}$ of distilled water in $1000 \mathrm{~cm}^{3}$ of volumetric flask. It was dissolved by agitation after which the volume was filled to the mark with deionized water.

3 Chromium solution: $4.527 \mathrm{~g}$ of $\mathrm{CrSO}_{4} 7 \mathrm{H}_{2} \mathrm{O}$ was added in the $100 \mathrm{~cm}^{3}$ of distilled water in $1000 \mathrm{~cm}^{3}$ volumetric flask. It was dissolved by agitation after which the volume was filled to the mark with deionized water

\section{Analysis of the adsorbent}

The broad method was employed for this study and is given as follows: The two sample adsorbent was weighed for $2.5 \mathrm{~g}$ each and was equilibrated with $100 \mathrm{~cm}^{3}$ of each metal $(\mathrm{Cr}, \mathrm{Pb}$, and $\mathrm{Ni}$ ) solution concentration of $50 \mathrm{ppm}$ and $100 \mathrm{ppm}$ in a stoppered borosil glass flask at a fixed temperature for $30^{\circ} \mathrm{C}$ in an orbital shaker for a period of time which is (30-60 min). After the equilibration, each 
sample of $10 \mathrm{~cm}^{3}$ was collected from each flask. In a time interval of 30 and $60 \mathrm{~min}$, the suspension of the adsorbent was separated from the solution by filtration using a filter paper $10 \mathrm{~cm}$ of each sample was collected for atomic absorption spectrophotometer (AAS) determinations.

\section{Results}

The result of the analysis is presented in tables, containing a full description of the analysis of variance done on the models and a 3-dimensional pictorial representation of the percentage of heavy metals removed and the factors responsible for the change.

Percentage Removal of Lead $(\mathrm{Pb})$ using tea bag residues as adsorbent ANOVA for selected factorial model

$$
\operatorname{Removal}(E) T B=91.654+0.186(E)+0.053(\text { Conc })
$$

\section{Discussion}

The Model $F$ value of 108.24 shows that there is a $6.78 \%$ probability that a "Model $F$ value" this large could be a result of interference, impurity or noise. If the probability value is greater than the fishers test "Prob $>F^{\prime}$ ", that is, less than 0.0500 level, this indicates that the terms of the model are significant. It was noted that statistically when the value of the terms or factors appearing in the model is greater than 0.1000 , it signifies the model terms are not significant. While optimizing the model, there were some model terms that appear insignificant, and so they were removed in order to improve our model.

\begin{tabular}{llll}
\hline SD & 0.20 & $R^{2}$ & 0.9954 \\
Mean & 96.45 & Adj $R^{2}$ & 0.9862 \\
C.V. \% & 0.21 & Pred $R^{2}$ & 0.9264 \\
Press & 0.64 & Adeq precision & 22.748 \\
\hline
\end{tabular}

The plot in Fig. 1 gives a clear picture of the effect of interactions of the factors on the response; the plot shows that percentage removal of lead decreases at constant $\mathrm{pH}$ of 1 , when the concentration of the solution containing the metal ions increases. The plot reflects the response behaviour to improve at high concentration, when the $\mathrm{pH}$ is alkaline. The validation plot of the model is shown in Fig. 2, the plot supports the ANOVA statistics that gives a close correlation between the response predicted by the model and the actual values of the experimental response.

\section{Percentage removal of lead $(\mathrm{Pb})$ using groundnut shell (GS) as adsorbent ANOVA for selected factorial model}

$$
\operatorname{Removal}(\mathrm{Pb}) G S=93.497+0.053(\text { Conc })-0.029(\text { Time })
$$

The "Model $F$ value" of 26.07 implies the model is not significant relative to the noise. There is a $13.72 \%$ probability that a "Model $F$ value" this large could be a result of interference, impurity or noise. If the probability value is greater than the fishers test "Prob $>\mathrm{F}$ ", that is, less than 0.0500 level, this indicates that the terms of the model are significant (Figs. 3, 4, 5, 6, 7, 8, 9, 10, 11, 12).
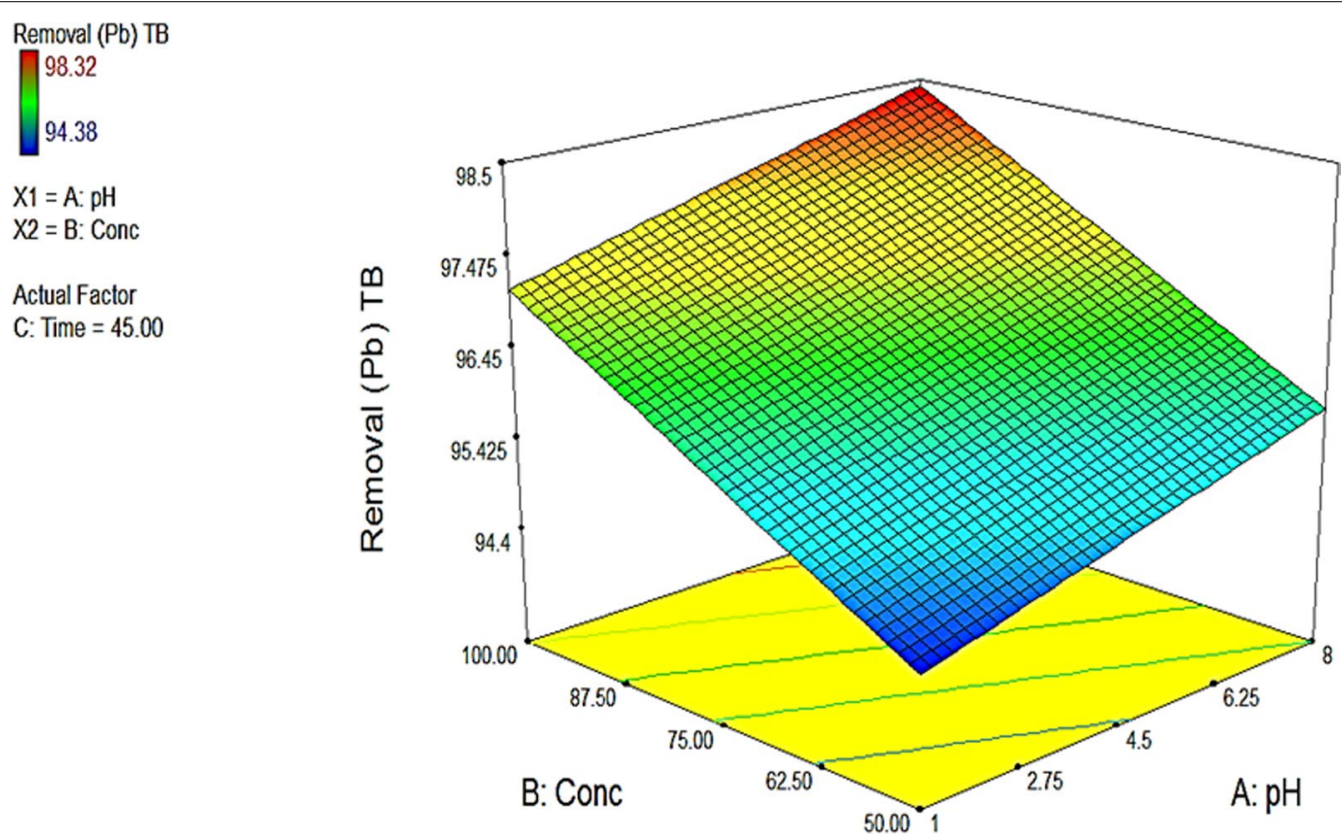

Fig. 1 A 3-dimensional plot of concentration and pH against the percentage removal of lead when tea bag residues are used as adsorbent 
Design-Expert@ Software Removal (Pb) TB

Color points by value of Removal (Pb) TB:

98.32

94.38

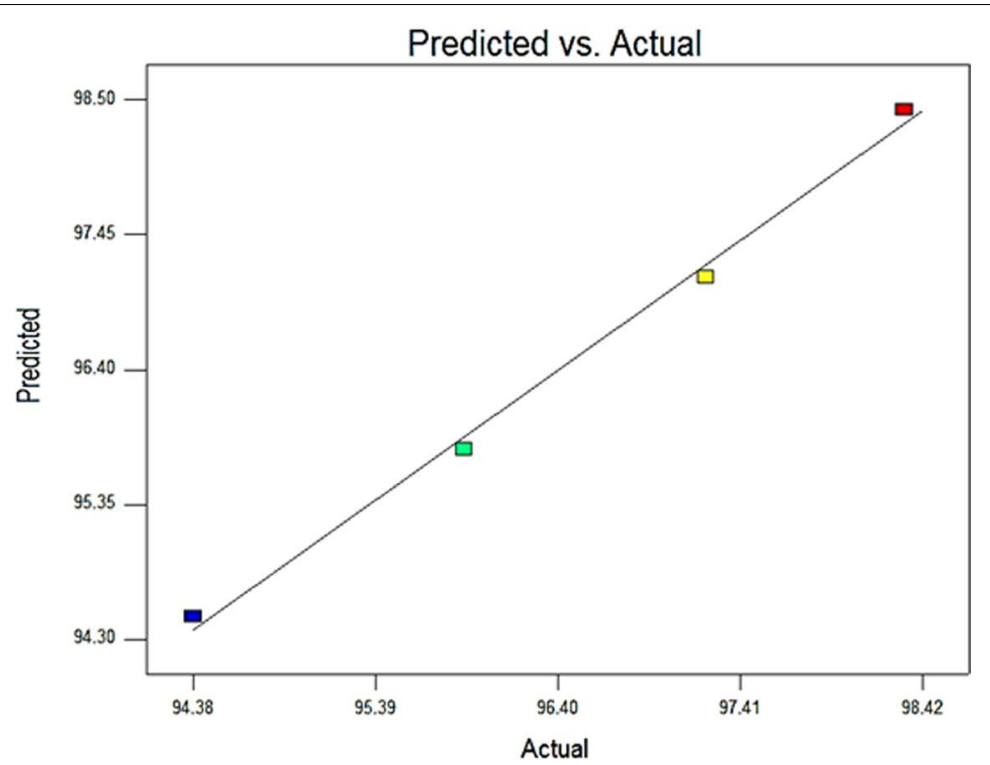

Fig. 2 A cross-validation plot predicted response against actual values of response from selected factorial model on the removal of lead when tea bag residues are used as adsorbent
Design-Expert@ Software

Removal (Pb) GS

Color points by value of Removal (Pb) GS:

97.74

94.24

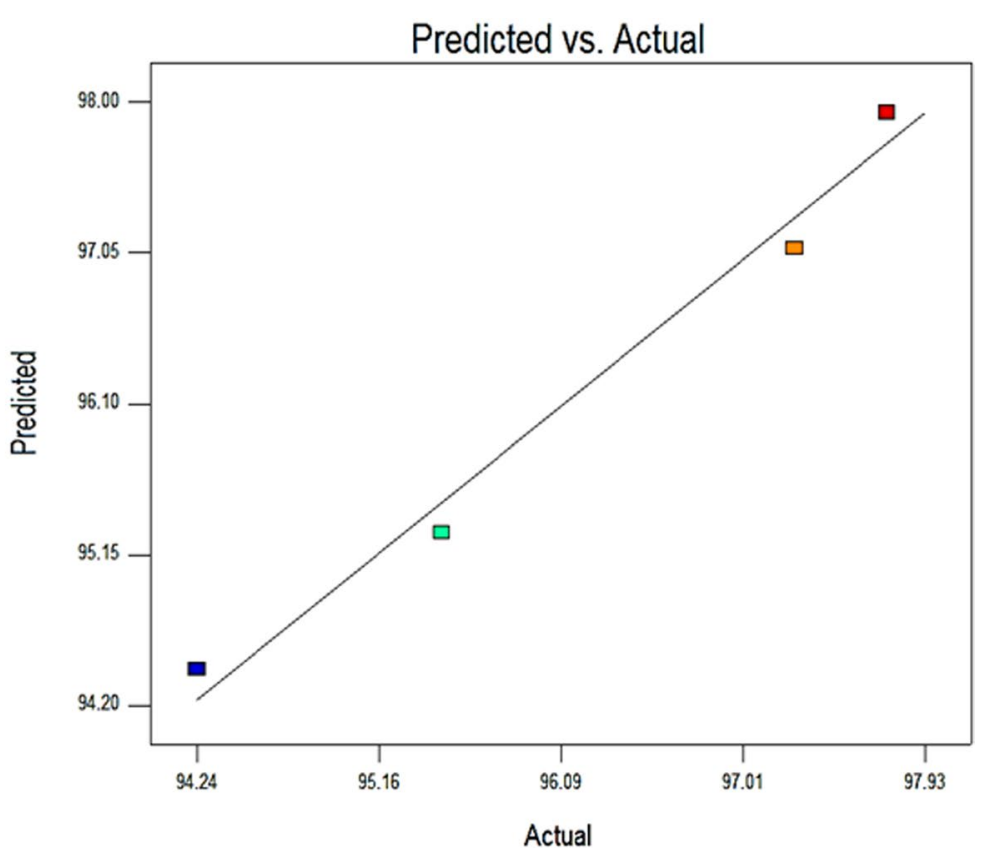

Actual

Fig. 3 A cross-validation plot of predicted response against actual values of response from selected factorial model on the removal of lead when groundnut shell residues are used as adsorbent

The "Pred $R^{2 "}$ of 0.6989 is not as close to the "Adj $R^{2 "}$ of 0.9435 as one might normally expect. This may indicate a large block effect or a possible problem with your model and/or data. Things to consider are model reduction, response transformation, outliers, etc. "Adeq
Precision" measures the signal-to-noise ratio. A ratio greater than 4 is desirable. Your ratio of 10.497 indicates an adequate signal. This model can be used to navigate the design space. 
Removal (Pb) GS

97.74

94.24

$\mathrm{X} 1=\mathrm{B}:$ Conc

$\mathrm{X} 2=\mathrm{C}:$ Time

Actual Factor

A: $\mathrm{pH}=4.50$

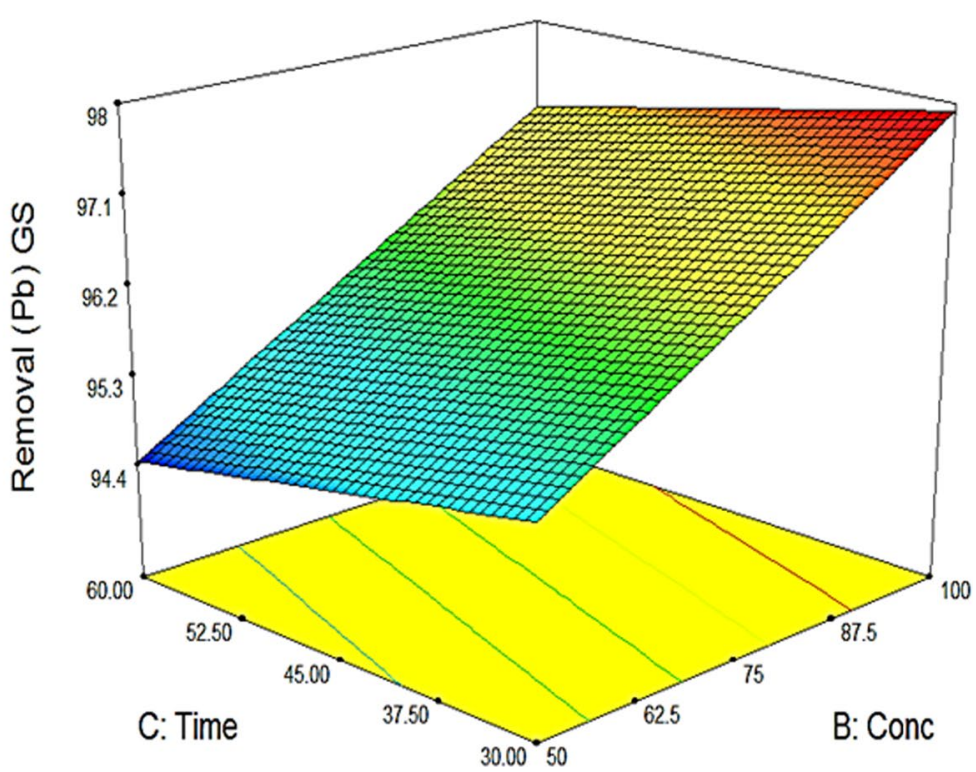

Fig. 4 A 3-dimensional plot of concentration and pH against the percentage removal of lead when groundnut shell residues are used as adsorbent

Design-Expert@ Software

Removal (Cr) TB

Color points by value of

Removal (Cr) TB

99.93

96.45

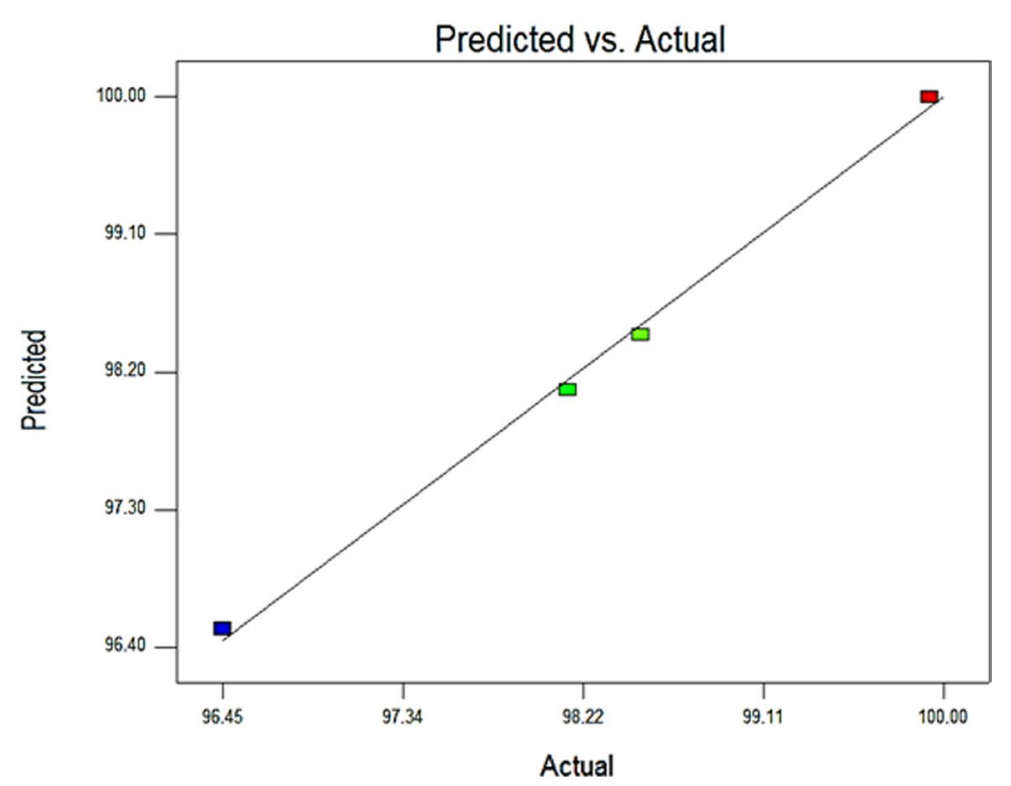

Fig. 5 A cross-validation plot predicted response against actual values of response from selected factorial model on the removal of chromium when tea bag residues are used as adsorbent

\section{Percentage removal of chromium $(\mathrm{Cr})$ using tea bag} residues as adsorbent ANOVA for selected factorial model

$\operatorname{Removal}(\mathrm{Cr}) T B=97.154-0.274(\mathrm{pH})+0.052($ Time $)$

The Model $F$ value of 156.12 implies there is a $5.65 \%$ chance that a "Model $F$ value" this large could occur due to noise.

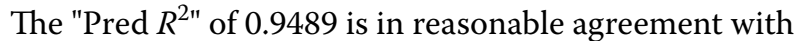
the "Adj $R^{2 "}$ of 0.9904. "Adeq Precision" measures the signal-to-noise ratio. A ratio greater than 4 is desirable. Your ratio of 28.703 indicates an adequate signal. This model can be used to navigate the design space. 
Removal (Cr) TB

99.93

96.45

$\mathrm{X} 1=\mathrm{A}: \mathrm{pH}$

$\mathrm{X} 2$ = B: Conc

Actual Factor

C: Time $=45.00$

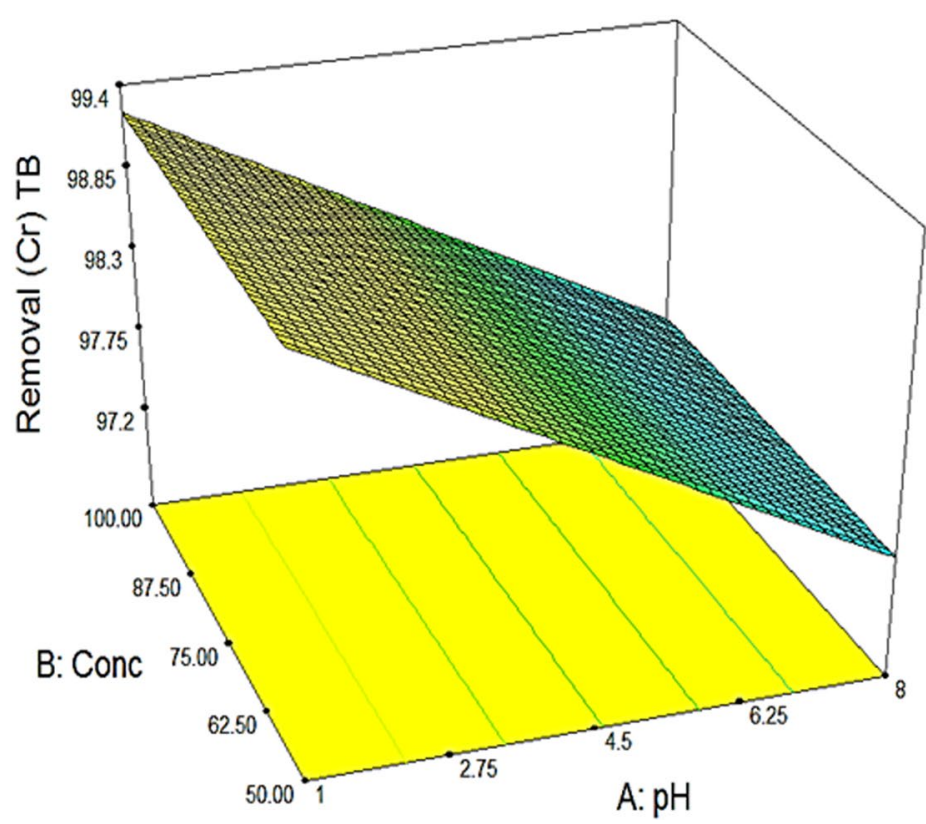

Fig. 6 A 3-dimensional plot of concentration and pH against the percentage removal of chromium when tea bag residues are used as adsorbent

Design-Expert@ Software

Removal (Cr) GS

Color points by value of Removal (Cr) GS:

99.5

96.5

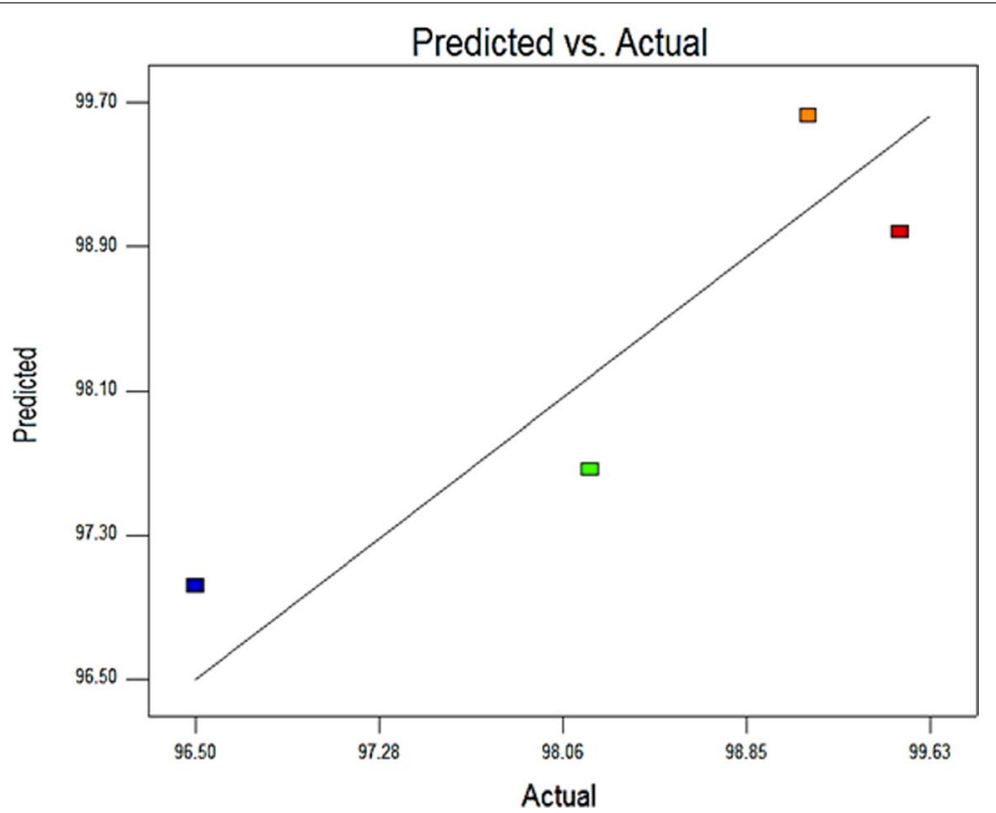

Fig. 7 A cross-validation plot predicted response against actual values of response from selected factorial model on the removal of chromium when groundnut shell residues are used as adsorbent

\begin{tabular}{llll}
\hline SD & 0.14 & $R^{2}$ & 0.9968 \\
\hline Mean & 98.26 & Adj $R^{2}$ & 0.9904 \\
C.V. \% & 0.14 & Pred $R^{2}$ & 0.9489 \\
PRESS & 0.31 & Adeq precision & 28.703 \\
\hline
\end{tabular}

Percentage removal of chromium $(\mathrm{Cr})$ using groundnut shell (GS) ANOVA for selected factorial model

$$
\operatorname{Removal}(E) \mathrm{GS}=94.407+0.013(\text { Conc })+0.066(\text { Time })
$$




Removal (Cr) GS
$\begin{aligned} & \text { X1 } 99.5 \\ & 96.5\end{aligned}$
X2 = C: Time
Actual Factor
A: pH = 4.50

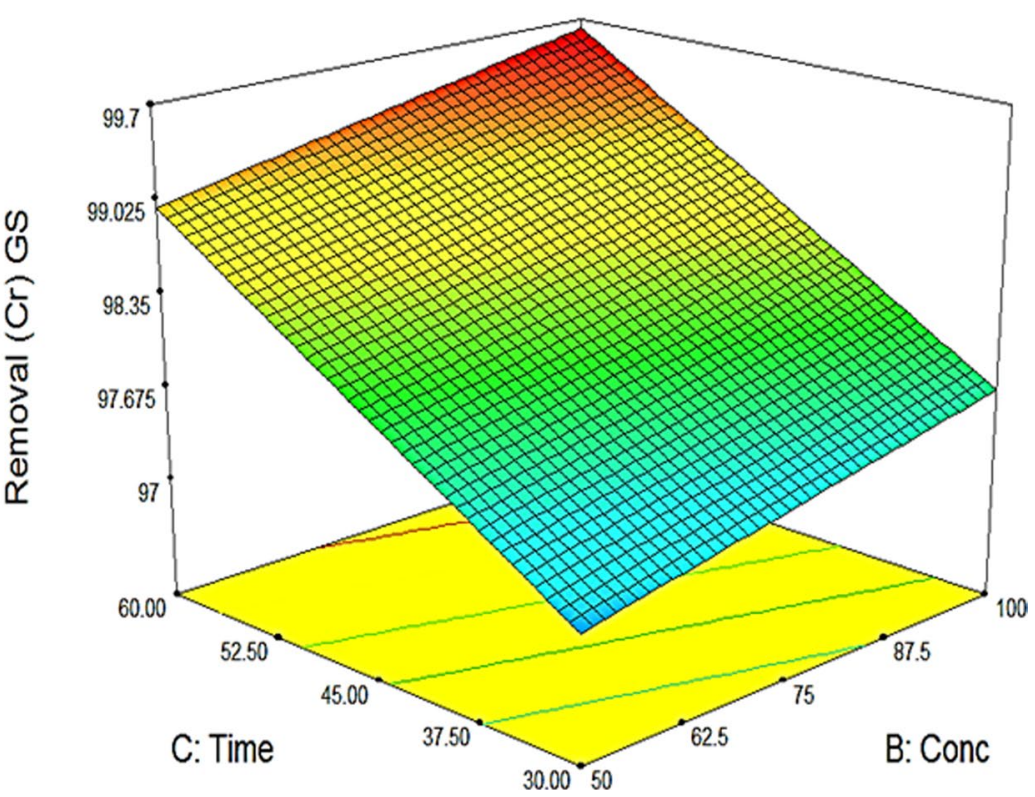

Fig. 8 A 3-dimensional plot of concentration and pH against the percentage removal of chromium when groundnut shell residues are used as adsorbent

Design-Experto Software

Removal (Ni) TB

Color points by value of Removal (Ni) TB:

94.77

85.64

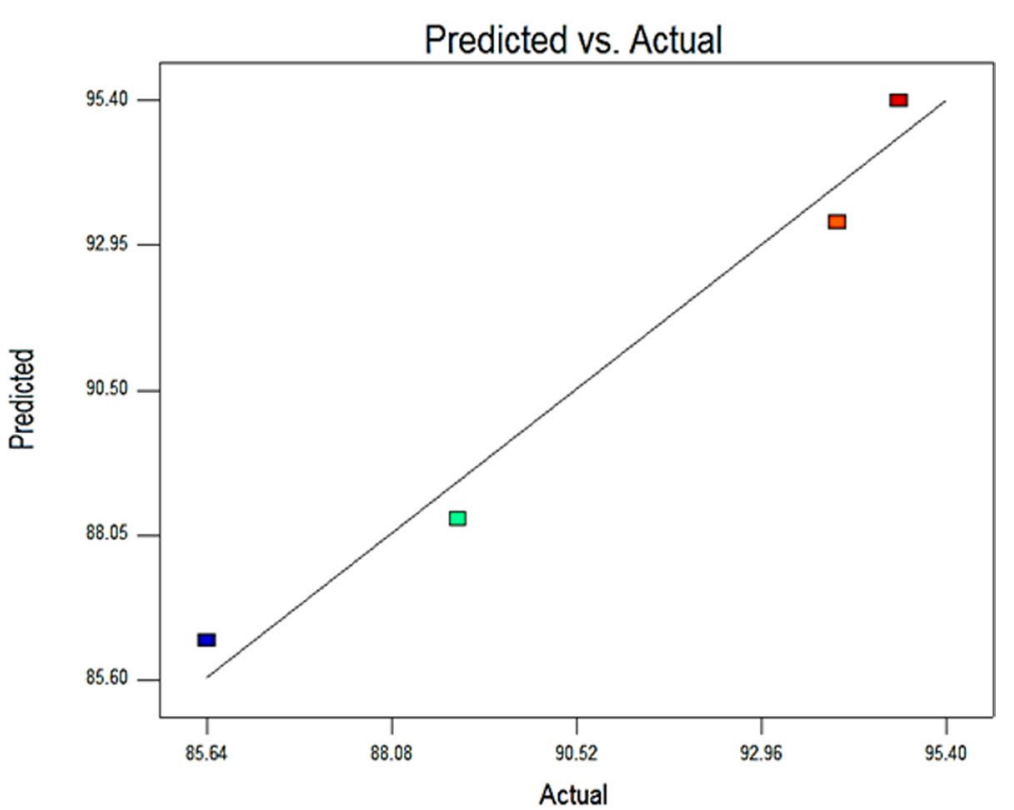

Fig. 9 A cross-validation plot predicted response against actual values of response from selected factorial model on the removal of Nickel when tea bag residues are used as adsorbent

The "Model $F$ value" of 2.00 implies the model is not significant relative to the noise. There is a $44.75 \%$ chance that a "Model $F$ value" this large could occur due to noise.

\begin{tabular}{llll}
\hline SD & 1.03 & $R^{2}$ & 0.7997 \\
Mean & 98.32 & Adj $R^{2}$ & 0.3991 \\
C.V. \% & 1.05 & Pred $R^{2}$ & 2.2046 \\
Press & 17.14 & Adeq precision & 2.912 \\
\hline
\end{tabular}




\section{Removal (Ni) TB \\ 94.77 \\ 85.64}

$\mathrm{X} 1=\mathrm{B}$ : Conc $\mathrm{X}_{2}=\mathrm{C}:$ Time

Actual Factor

$\mathrm{A}: \mathrm{pH}=4.50$

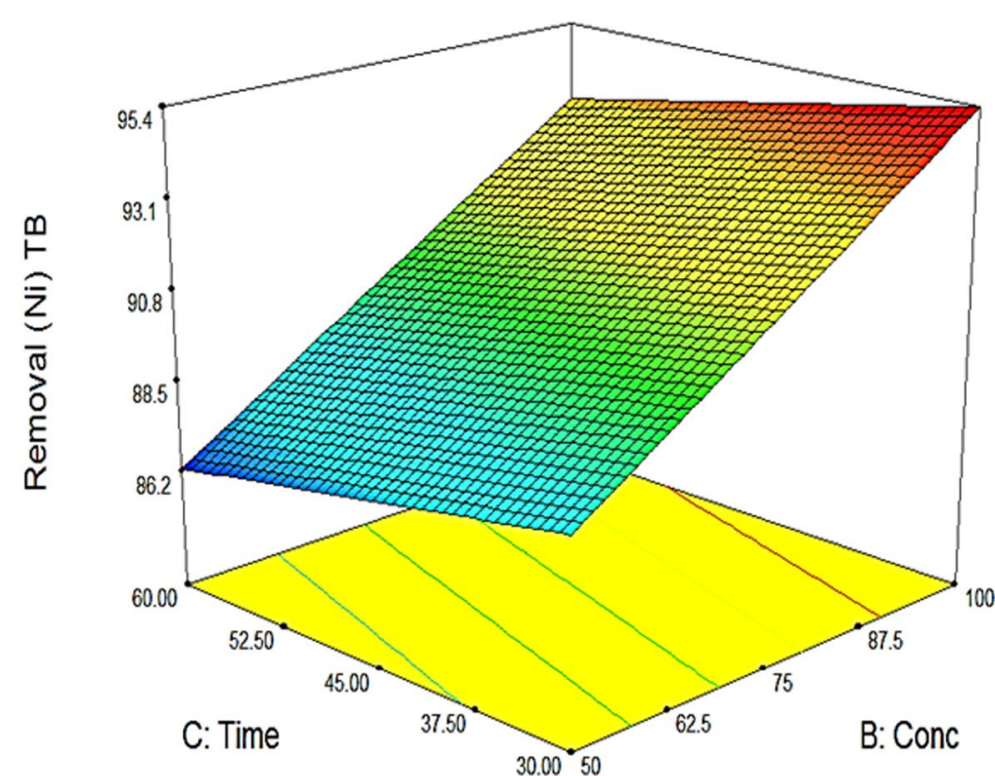

Fig. 10 A 3-dimensional plot of concentration and pH against the percentage removal of Nickel when tea bag residues are used as adsorbent
Design-Expert? Software

Removal (Ni) GS

Color points by value of

Removal (Ni) GS

94.15

86.6

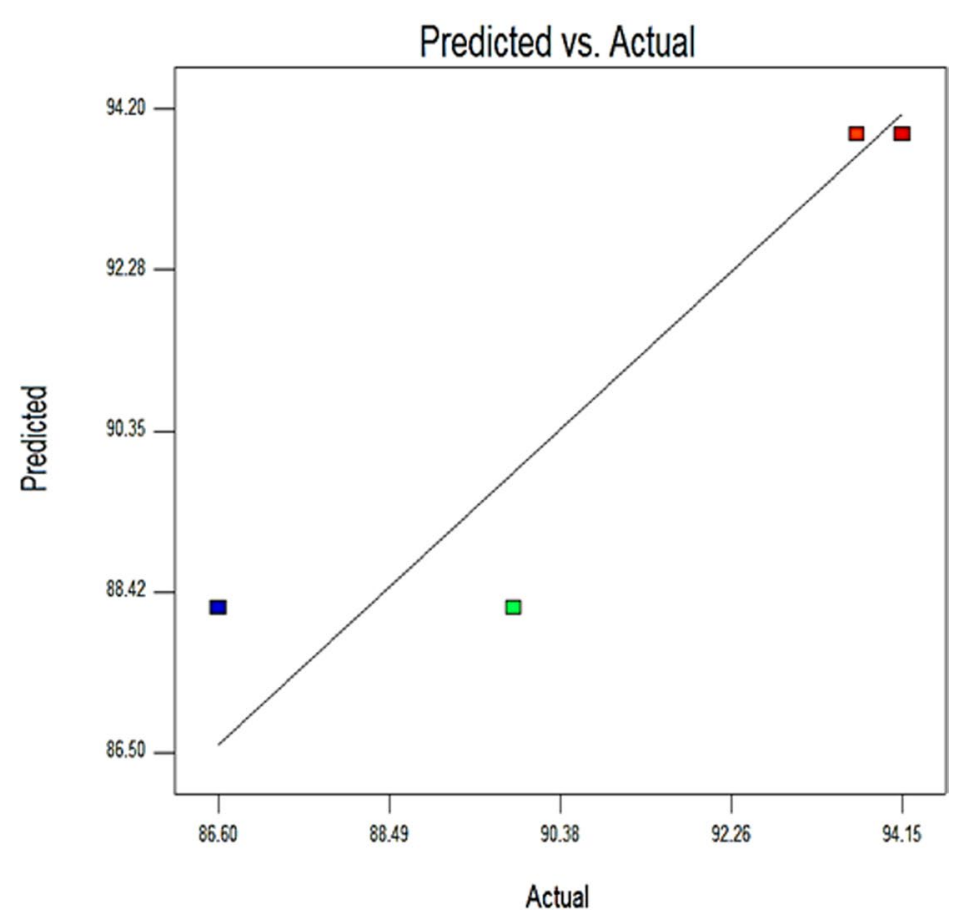

Fig. 11 A cross-validation plot predicted response against actual values of response from selected factorial model on the removal of Nickel when groundnut shell residues are used as adsorbent 


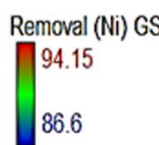

$\mathrm{X} 1=\mathrm{C}$. Time

$\mathrm{X} 2=\mathrm{A}: \mathrm{pH}$

Actual Factor

B: Conc $=75.00$

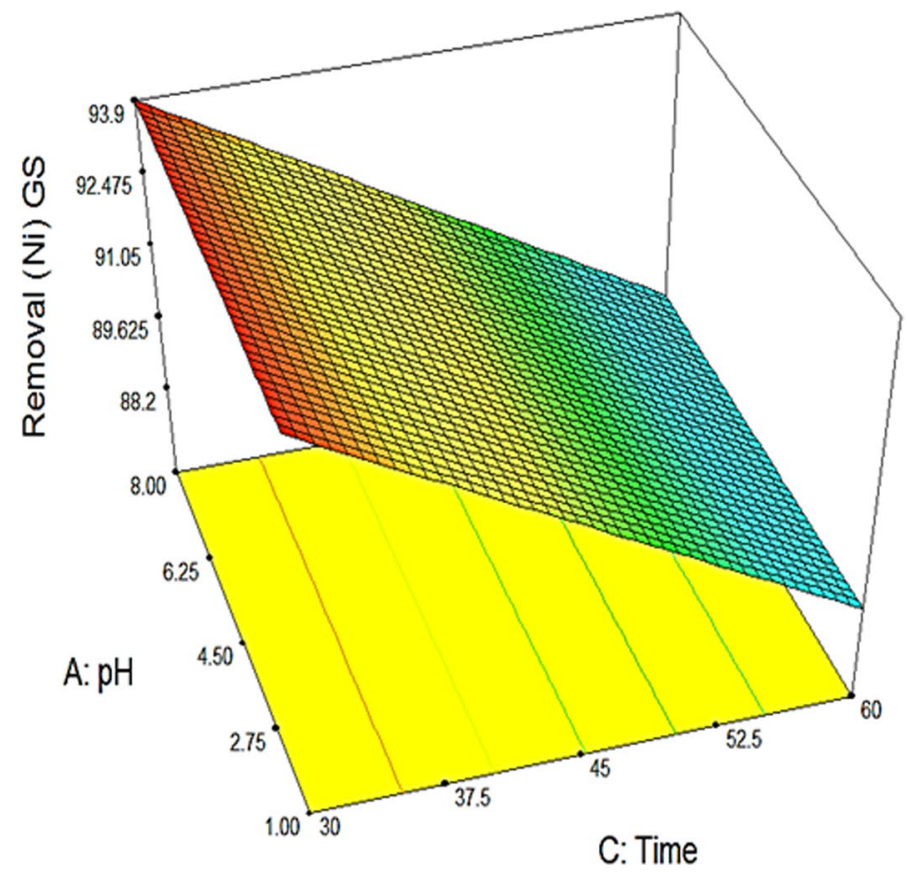

Fig. 12 A 3-dimensional plot of concentration and $\mathrm{pH}$ against the percentage removal of Nickel when groundnut shell residues are used as adsorbent

A negative "Pred $R^{2 "}$ implies that the overall mean is a better predictor of your response than the current model. "Adeq Precision" measures the signal-to-noise ratio. A ratio of 2.91 indicates an inadequate signal, and we should not use this model to navigate the design space.

\section{Percentage removal of nickel (Ni) using tea bag residues as adsorbent ANOVA for selected factorial model}

$$
\text { Removal }(\mathrm{Ni}) \mathrm{TB}=83.315+0.141(\mathrm{Conc})-0.0686(\text { Time })
$$

The "Model $F$ value" of 17.35 implies the model is not significant relative to the noise. There is a $16.74 \%$ chance that a "Model $F$ value" this large could occur due to noise.

\begin{tabular}{llll}
\hline SD & 1.25 & $R^{2}$ & 0.9720 \\
Mean & 90.83 & Adj $R^{2}$ & 0.9160 \\
C.V.\% & 1.38 & Pred $R^{2}$ & 0.5519 \\
Press & 25.00 & Adeq precision & 8.434 \\
\hline
\end{tabular}

The "Pred $R^{2 "}$ of 0.5519 is not as close to the "Adj $R^{2 "}$ of 0.9160 as one might normally expect. This may indicate a large block effect or a possible problem with your model and/or data. Things to consider are model reduction, response transformation, outliers, etc. "Adeq Precision" measures the signal-to-noise ratio. A ratio greater than 4 is desirable. Your ratio of 8.434 indicates an adequate signal. This model can be used to navigate the design space.

\section{Percentage removal of nickel (Ni) using groundnut shell (GS) ANOVA for selected factorial model}

$$
\text { Removal (Ni) GS }=99.570-0.189(\text { Time })
$$

The Model $F$ value of 11.82 implies there is a $7.52 \%$ chance that a "Model $F$ value" this large could occur due to noise.

\begin{tabular}{llll}
\hline SD & 1.65 & $R^{2}$ & 0.8553 \\
Mean & 91.06 & Adj $R^{2}$ & 0.7830 \\
C.V.\% & 1.81 & Pred $R^{2}$ & 0.4212 \\
PRESS & 21.76 & Adeq precision & 4.863 \\
\hline
\end{tabular}

The "Pred $R^{2 "}$ of 0.4212 is not as close to the "Adj $R^{2 "}$ of 0.7830 as one might normally expect. This may indicate a large block effect or a possible problem with your model and/or data. Things to consider are model reduction, response transformation, outliers, etc. "Adeq Precision" measures the signal-to-noise ratio. A ratio greater than 4 is desirable. Your ratio of 4.863 indicates an adequate signal. This model can be used to navigate the design space.

\section{Conclusion}

The present research shows that groundnut shell and tea bag can effectively be used as excellent adsorbent for the removal of $\mathrm{Ni}, \mathrm{Pb}$, and $\mathrm{Cr}$ from aqueous solution. 
This study also highlights the effect of different parameters such as, contact time, $\mathrm{pH}$, initial concentration, and adsorbent dose in removal of metal ions.

\section{Availability of data and material}

All data and material are available upon request (Tables 1 , $2,3,4,5,6,7)$.

Table 1 Taguchi design of the experiment

\begin{tabular}{lll}
\hline Factor $1 \mathbf{p H}$ & $\begin{array}{l}\text { Factor } 2 \text { concentration } \\
\text { in (ppm) }\end{array}$ & $\begin{array}{l}\text { Factor } \\
\mathbf{3} \text { time } \\
\text { in (min)s }\end{array}$ \\
\hline 1.00 & 100.00 & 60.00 \\
1.00 & 50.00 & 30.00 \\
8.00 & 50.00 & 60.00 \\
8.00 & 100.00 & 30.00 \\
\hline
\end{tabular}

Table 2 Analysis of variance [partial sum of squares-Type III]

\begin{tabular}{llllll}
\hline Source & $\begin{array}{l}\text { Sum } \\
\text { of squares }\end{array}$ & Df & Mean Square & F Value & $\begin{array}{l}\text { p-value } \\
\text { Prob }>\text { F }\end{array}$ \\
\hline Model & 32.15 & 1 & 32.15 & 11.82 & 0.0752 \\
C-time & 32.15 & 1 & 32.15 & 11.82 & 0.0752 \\
Residual & 5.44 & 2 & 2.72 & & \\
Cor total & 37.59 & 3 & & & \\
\hline
\end{tabular}

Table 3 Analysis of variance table [partial sum of squares-type III]

\begin{tabular}{llllll}
\hline Source & $\begin{array}{l}\text { Sum } \\
\text { of squares }\end{array}$ & Df & Mean square & F value & $\begin{array}{l}\boldsymbol{P} \text { value } \\
\text { Prob }>\text { F }\end{array}$ \\
\hline Model & 7.73 & 2 & 3.86 & 26.07 & 0.1372 \\
B-time & 7.00 & 1 & 7.00 & 47.20 & 0.0920 \\
Residual & 0.73 & 1 & 0.73 & 4.93 & 0.2694 \\
Cod total & 0.15 & 1 & 0.15 & & \\
\hline
\end{tabular}

Table 4 Analysis of variance table [partial sum of squares-Type III]

\begin{tabular}{llllll}
\hline Source & $\begin{array}{l}\text { Sum } \\
\text { of squares }\end{array}$ & Df & Mean square & F value & $\begin{array}{l}\boldsymbol{p} \text { Value } \\
\text { Prob }>\text { F }\end{array}$ \\
\hline Model & 6.12 & 2 & 3.06 & 156.12 & 0.0565 \\
A-pH & 3.69 & 1 & 3.69 & 188.08 & 0.0463 \\
C-time & 2.43 & 1 & 2.43 & 124.16 & 0.0570 \\
Residual & 0.020 & 1 & 0.020 & & \\
Cor total & 6.14 & 3 & & & \\
\hline
\end{tabular}

Table 5 Analysis of variance table [partial sum of squares-Type III]

\begin{tabular}{llllll}
\hline Source & $\begin{array}{l}\text { Sum } \\
\text { of squares }\end{array}$ & Df & Mean square & F value & $\begin{array}{l}\boldsymbol{p} \text { Value } \\
\text { Prob }>\text { F }\end{array}$ \\
\hline Model & 4.28 & 2 & 2.14 & 2.00 & 0.4475 \\
B-conc & 0.42 & 1 & 0.42 & 0.39 & 0.6452 \\
C-time & 3.86 & 1 & 3.86 & 3.60 & 0.3086 \\
Residual & 1.07 & 1 & 1.07 & & \\
Cor total & 5.35 & 3 & & & \\
\hline
\end{tabular}

Table 6 Analysis of variance table [partial sum of squares-Type III]

\begin{tabular}{llllll}
\hline Source & $\begin{array}{l}\text { Sum } \\
\text { of squares }\end{array}$ & Df & Mean square & F value & $\begin{array}{l}\boldsymbol{p} \text { Value } \\
\text { Prob }>\text { F }\end{array}$ \\
\hline Model & 54.23 & 2 & 27.11 & 17.35 & 0.1674 \\
B-conc & 49.98 & 1 & 49.98 & 31.99 & 0.1114 \\
C-time & 4.24 & 1 & 4.24 & 2.72 & 0.3472 \\
Residual & 1.56 & 1 & 1.56 & & \\
Cor total & 55.79 & 3 & & & \\
\hline
\end{tabular}

Table 7 Analysis of variance table [Partial sum of squares-Type III]

\begin{tabular}{llllll}
\hline Source & $\begin{array}{l}\text { Sum } \\
\text { of squares }\end{array}$ & Df & Mean square & F value & $\begin{array}{l}\boldsymbol{p} \text { Value } \\
\text { Prob }>\text { F }\end{array}$ \\
\hline Model & 32.15 & 1 & 32.15 & 11.82 & 0.0752 \\
C-time & 32.15 & 1 & 32.15 & 11.82 & 0.0752 \\
Residual & 5.44 & 2 & 2.72 & & \\
Cor total & 37.59 & 3 & & & \\
\hline
\end{tabular}

Acknowledgements

Not applicable

Authors' contributions

DEA designed the study and analysed the result, while AAO interpreted the result and was a major contributor in writing the manuscript. All authors read and approved the final manuscript.

Funding

No funding was received.

Ethics approval and consent to participate Not applicable.

Consent for publication

Not applicable.

\section{Competing interests}

No competing interests to declare.

Author details

${ }^{1}$ Department of Chemistry, Baze University Abuja, Abuja, Nigeria. ${ }^{2}$ Department of Chemistry, Ahmadu Bello University Zaria, Zaria, Nigeria. 
Received: 14 August 2020 Accepted: 25 November 2020

Published online: 09 January 2021

\section{References}

AL-Sdi A, Al-Asitu S, Al Ajmi A, Raut NG (2012) A crital review of removal of zinc from waste water. In: Proceeding of the word congress on engineering. vol 1, WCE 2012, July 4-6, 2012, Loodon

Abdel-Shafy HI (2015) Chemical treatment for removal of heavy metals from industrial wastewater. Egy J Chem 58(1):1-12

Abdel-Shafy HI, Mansour MS (2018) Phytoremediation for the elimination of metals, pesticides, PAHs, and other Pollutants from wastewater and soil. In: Phytobiont and ecosystem restitution, Springer, Berlin, pp 101-136

Abdel-Shafy HI, Abdel-Sabour MF, Aly RO (1998) Adsorption of nickel and mercury from drinking water simulant by activated carbon. Environ Manag Health

Allure HK (2007) Biosorption, and ecofriendly alternative for heavy metal removal. Afr J Biotech 6(25):29-31

Amarasinghe BMWPK, Williams RA (2007) Use tea waste as a low cost adsorbent water, chemical. Eng J 132:299-309

Beliles RP (2007) Chi lesser metals. In: Ochme FW (ed) Toxicity of heavy metals in the environment; part 2. Mercel Dekker, New York, p 383

Cay SIU, Yamik A, Osiki A (2004) Single and binary competitive adsorption of copper(II) and Cd(II) from aqueous solution using tea industry waste. Seg Purification, Technol 38:273-280

Chu W (2001) Oye removal from textile, dye waste water using recycle alum. Sludge Water Resour 35(13):3147-3152

Henderson AL, Schmitt TC, Heinze TM, Cerniglia CE (1997) Reduction of malachite green to leucomalachite green by intestinal bacteria. Appl Environ Microbiol 63(10):4099-4101

Kadviru K, Themaraised V, Namasiviam C (2001) Removal of heavy metal from industrial waste water. Technology 76:63-65
Khan MN, Wahab MF (2006) Characterization of chemically modified corncobs and its application in the removal of metal ions from aqueous solution. Hazard Matter B141:237-244

Kin J, Lee HB, Cho SH (2005) Preparation of poly (vinylpyrrolidone) coated iron oxide nanoparticles for contrast agent. Polymer (Korea) 29(3):266-270

Mahavi AH, Naghipour D, Vaezi F, Nazmara S (2005) Tea waste as an adsorbent for heavy metal removal from industrial waste water. Am J Appl Sci 2(1):372-375

Malkoc E, Nuhoglu Y (2005) Investigations of nickel from aqueous using tea factory waste. J Hazardous Mater B127:120

Nguyen C, Do DD (2001) The Dubinin-Radushkevich equation and the underlying microscopic adsorption description. Carbon 39(9):1327-1336

Parasad B, Muhamad A, Wasewar KL (2008) Characterization of factory tea waste on adsorbent for removal of heavy metal using tea waste adsorbent. J Fut Eng Techol 3(3):47-53

Parker P (1999) Encyclopedia of environment scunce. MC.Graw H.II, New York

Taguchi G (1995) Quality engineering (Taguchi methods) for the development of electronic circuit technology. IEEE Trans Reliab 44(2):225-229

Taguchi G, Jugulum R (2002) The Mahalanobis-taguchi strategy: a pattern technology system. Wiley, New York

Taguchi G, Konishi S (1987) Taguchi methods, orthogonal arrays and linear graphs, tools for quality American supplier institute. American supplier institute, Egypt, pp 8-35

Ward (1995) Environment analytical chemistry. Trace element Polockie Academic and professional, London

\section{Publisher's Note}

Springer Nature remains neutral with regard to jurisdictional claims in published maps and institutional affiliations.

\section{Submit your manuscript to a SpringerOpen ${ }^{\circ}$ journal and benefit from:}

- Convenient online submission

- Rigorous peer review

- Open access: articles freely available online

- High visibility within the field

- Retaining the copyright to your article

Submit your next manuscript at springeropen.com 